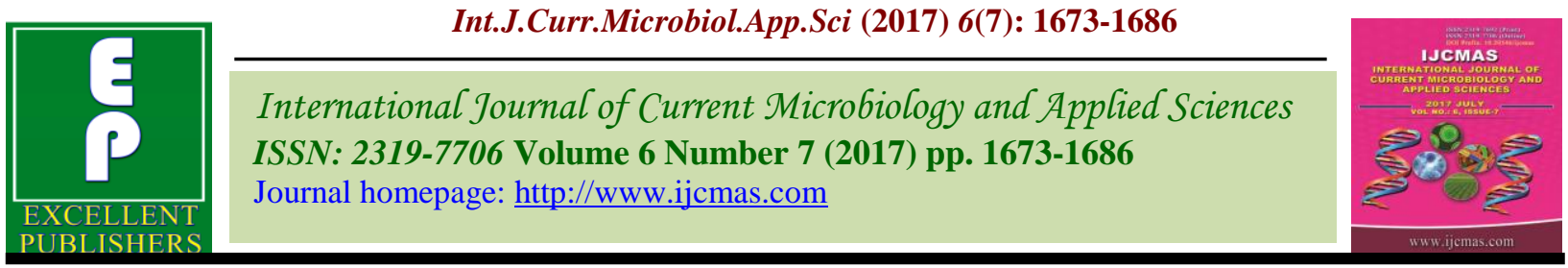

Original Research Article

https://doi.org/10.20546/ijcmas.2017.607.202

\title{
Pathogens Associated with Micropropagated Banana Plantlets and their Management with Microbial Bioagents
}

\author{
Joli Dutta ${ }^{*}$ and L.C. Bora \\ Department of Plant Pathology, Assam Agricultural University, Jorhat- 785013, Assam, India \\ *Corresponding author
}

\section{A B S T R A C T}

\section{Keywords}

Micropropagated

Banana,

Colletotrichum

musae,

Antagonistic

microorganisms.

Article Info

Accepted:

19 June 2017

Available Online:

10 July 2017
Four antagonistic microorganisms Trichoderma viride, Metarhizium anisopliae, Pseudomonas fluorescens and Bacillus thuringiensis and their consortia were used to suppress Colletotrichum musae (Berk and Curtis), the causal agent of anthracnose disease of micropropagated banana during 2014-16. The compatibility tests conducted in vitro among these bioagents showed that all the bioagents were compatible amongst themselves. The consortia of different antagonists were tested to assay their ability to inhibit the growth of $C$. musae in vitro. The inhibition produced by the consortia of four bioagents $T$. viride, $P$. fluorescens, $M$. anisopliae and $B$. thuringiensis was significantly highest against $C$. musae $(80.56 \%)$. The efficacy of the microbe based consortial formulations was also tested for their ability to suppress diseases caused by $C$. musae in vivo in pot grown micropopagated banana plantlets. There was a significant reduction of anthracnose disease incidence accompanied by enhancement of yield attributing characters in banana due to the application of consortial formulation of bioagents applied as root treatment and soil treatment.

\section{Introduction}

Micropropagation is the rapid multiplication of stock plant material to produce a large number of progeny plants under aseptic conditions using modern plant tissue culture methods. An ideal tissue culture raised plant should be free from diseases.

The pathogenic microbes generally get associated with tissue cultured banana plantlets includes, Fusarium oxysporum $f$. sp. cubense (Fusarium wilt or Panama disease); Pythium sp. (Damping off); Rhizoctonia solani (Root rot); Ralstonia solanacearum (Moko disease); Erwinia carotovora (soft rot) and Colletotrichum musae (Anthracnose). Banana anthracnose caused by $C$. musae, is considered as one of the major constraints to banana production. It deteriorates the quality and nutritive value of the fruits which is unfit for consumption and marketing.

Sunken brown spots develop on ripe fruits with orange acervuli (Lim et al., 2002).

The objective of the present study is to screen different antagonistic microorganisms, development of microbial consortia and test their ability to inhibit the growth of fungal 
pathogen, C. musae and reduce diseases caused by $C$. musae in micropropagated banana and corresponding enhancement of plant growth and yield attributing characters.

\section{Materials and Methods}

\section{Microbial isolation}

The infected lesions of micro-propagated banana plantlets were collected for isolation of fungal pathogen, C. musae. The isolated culture was preserved in refrigerator at $4^{\circ} \mathrm{C}$ for subsequent use. Pathogenicity test was conducted in one month old potted micropropagated banana (var. G 9) plantlets, following injection-infiltration method. Characterization of the fungal pathogen was done following the guidelines described by Alexopolous et al., 1996. The pure culture of microbial bioagents viz., Trichoderma viride, Metarhizium anisopliae, Pseudomonas fluorescens and Bacillus thuringiensis used in the present study was collected from the culture bank of Programme on Biopesticides, Department of Plant Pathology, Assam Agricultural University, Jorhat.

\section{Evaluation of compatibility among} different bioagents and development of microbial consortia

Compatibility among the four microbial bioagents, viz., T. viride, $M$. anisopliae, $P$. fluorescens and $B$. thuringiensis were tested in vitro adopting dual culture essay plate technique (Aspiras and Cruz, 1985) using PDA as basal media. The treatment combinations were : Growth of $T$. viride alone, $M$. anisopliae alone, B. thuringiensis alone, $P$. fluorescens alone, $T$. viride $+M$. anisopliae, $T$. viride $+B$. thuringiensis, $T$. viride $+P$. fluorescens, $M$. anisopliae $+B$. thuringiensis, $M$. anisopliae $+P$. fluorescens, $B$. thuringiensis $+P$. fluorescens and $T$. viride $+M$. anisopliae $+B$. thuringiensis $+P$. fluorescens. The radial growth of each bioagents individually and in combination was recorded upto $120 \mathrm{~h}$ of incubation at $28 \pm 1{ }^{0} \mathrm{C}$, and tabulated for comparison.

\section{Inhibitory effects of bioagents against $C$.} musae

The inhibitory effect of bioagents against $C$. musae was evaluated in vitro using PDA as basal medium. Assay plates of $C$. musae were prepared by transferring mycelial disc of the pure culture of the fungus on PDA plates and incubated at $28 \pm 1{ }^{0} \mathrm{C}$ for $48 \mathrm{~h}$. Then, $0.5 \mathrm{~cm}$ diameter of fungal bioagent, $T$. viride grown in PDA was transferred to the center of PDA plates where $C$. musae was grown earlier. Following the same procedure, $0.5 \mathrm{~cm}$ bit of bioagents such as $M$. anisopliae, $B$. thuringiensis and $P$. fluorescens grown in PDA was scooped out and transferred to the center of PDA plates seeded earlier with $C$. musae. The plates were then incubated at $28 \pm 1^{\circ} \mathrm{C}$. The inhibitions produced were measured after $72 \mathrm{~h}$ of dual inoculations. The data were converted to percentage of inhibitions produced by the bioagents as compared to control.

Based on the percent of inhibitions shown by the antagonists or their combinations in vitro, 3 best treatment combinations were selected for their further evaluation as individual or consortia bioformulation in suppression of anthracnose disease of pot grown micropropagated banana plantlets.

Suppressive effects of bioagents and their consortia against anthracnose disease of micropopagated banana plantlets

For preparation of microbe based bioformulations, the antagonists were first grown in their specific media (either PDA, NA or Trichoderma specific medium). $T$. viride was transferred to PDA slants and 
incubated at $28 \pm 1^{\circ} \mathrm{C}$ for $48 \mathrm{~h}$. By mixing sterile distilled water to this growth, suspension of T.viride@ $10^{8} \mathrm{cfu} / \mathrm{ml}$ was prepared. A loop of the inoculum was transferred to 1 lit of PDA broth contained in a conical flask and after thorough stirring, after that, it was incubated at $28 \pm 1^{\circ} \mathrm{C}$ for 72 hrs to obtain a concentration of $10^{8} \mathrm{cfu} / \mathrm{ml}$. Following same protocol bioformulation of $M$. anisopliae, $B$. thuringiensis and $P$. fluorescens suspensions were prepared to obtain concentrations of $10^{8} \mathrm{cfu} / \mathrm{ml}$ for each bioagent. For preparation of consortial formulation, individual growth of $T$. viride, $B$. thuringiensis and $P$. fluorescens were adjusted @ $10^{8} \mathrm{cfu} / \mathrm{ml}$ and mixed at the ratio of 1: 1 . The treatment combinations compared under hydroponic tank conditions are as follows: $T$. viride alone; $M$. anisopliae alone, B. thuringiensis alone; P. fluorescens alone; $T$. viride $+B$. thuringiensis; $T$. viride+ $\mathrm{P}$. fluorescens; $P$. fluorescens $+B$. thuringiensis; T. viride+ P. fluorescens + B. thuringiensis.

\section{Method of application of treatments}

The three best consortial formulations applied as root treatment and soil application methods. For root treatment, properly cleaned roots of micropropagated plantlets were soaked in suspension of antagonists' broth for 1 hour prior to transplanting. Plantlets soaked in sterile water for 1 hour served as untreated control.

Soil treatment was done 30 days after transplanting. Soil near the base of the plants was loosened carefully and diluted suspension of antagonists broth $(100 \mathrm{ml}$ broth $+900 \mathrm{ml}$ distilled water) were applied @ 1 lit /plant. Plants treated with sterile water served as untreated control.

\section{Results and Discussion}

The fungal pathogen isolated from disease infected micropropagated banana plantlets was identified to be Colletotrichum musae. The pure culture of the fungus produced white coloured aerial mycelia, which covered the entire periphery of the PDA plate within 3-4 days of incubation at $28 \pm 1^{0} \mathrm{C}$. After 6-8 days of incubation, several black, acervulus-like masses were developed on the culture plates with orange exudates.

Conidia were aseptate, hyaline, mostly ellipsoid, ranging from 10-18 $\mu \mathrm{m}$ and 5-9 $\mu \mathrm{m}$ (average of 14.5-6.9 $\mu \mathrm{m}$ ) in size. Similar type of results of cultural and morphological characters was earlier recorded by Lim et al., (2002) during identification of C. musae. In the inoculated banana plantlets, some irregular, sunken leaf spots were observed within 7-8 days.

Similar types of results were recorded by (Xiao et al., 2004) up to 21 days after inoculation. Earlier, Meredith (1960) recorded that $C$. musae may form lesions on fruits without skin bruising but produces larger lesions when fruits are damaged. C. musae is also responsible for crown rot, blossom end rot, and tip rot of banana (Nazriya et al., 2007).

\section{Compatibility among different bioagents in vitro}

The compatibility tests among four different bioagents $T$. viride, $M$. anisopliae, $P$. fluorescens and $B$. thuringiensis were made following modified dual culture technique using PDA as basal medium, and was found that the bioagents were compatible amongst themselves. Earlier, Deuri (2013), reported positive compatibility amongst saprophytic antagonists like $P$. fluorescens, $T$. viride, $M$. anisopliae. Similar compatible observations amongst bioagents like $P$. fluorescens, T.viride, T. harzianum, M. anisopliae and Beauvaria bassiana was earlier recorded by Bora (2012) and Bora et al., (2013). 
Antagonism of bioagents against $C$. musae in vitro

The antagonistic potential of the four compatible bioagents, viz., T. viride, $M$. anisopliae, $P$. fluorescens and $B$. thuringiensis and their consortia were tested against $C$. musae adopting dual culture method using PDA as basal medium. All the four bioagents produced varying radial growth and showed corresponding suppression against $C$. musae in vitro. The combination of four bioagents $T$. viride, $P$. fluorescens, $M$. anisopliae and $B$. thuringiensis produced highest inhibition $(80.56 \%)$ followed by combination of $T$. viride, B. thuringiensis and $P$. fluorescens (68.22\%) against $C$. musae (Table 1).

The Trichoderma species are extremely versatile biocontrol agents which suppresses the diseases caused by different plant pathogens like Anthracnose and Grey mould in strawberry (Freeman et al., 2004). Trichoderma has the ability to produce a series of antibiotics and fungal cell walldegrading enzymes. These enzymes play important role in mycoparasitism and mycelial lysis of the target pathogenic microbe. The hydrolytic enzyme has been identified includes proteinase (Prb1). The present observation of antagonism of $T$. viride might be as a result of similar type of mechanisms of parasitism (Dagostin et al., 2008).

M. anisopliae has the ability to release three different secondary metabolites viz., destruxin A, destruxin E and cytochalasin D. Kang et al.,(1996) reported that M. anisopliae have antagonistic effects on various plant pathogens, including Fusarium oxysporium and Alternaria solani.

Table.1 Suppression of radial growth of pathogens by different Microbial bioagents and their consortia in vitro

\begin{tabular}{|c|c|c|}
\hline \multirow{2}{*}{ Treatments } & \multicolumn{2}{|c|}{ C. musae } \\
\hline & Radial growth & Inhibition \\
\hline Control & 90.0 & $0.00(0.57)$ \\
\hline Trichoderma viride & 33.3 & $63.04(52.61)$ \\
\hline Pseudomonas fluorescens & 80.3 & $10.77(19.08)$ \\
\hline Metarhizium anisopliae & 37.7 & $58.04(49.58)$ \\
\hline Bacillus thuringiensis & 65.3 & $27.37(31.52)$ \\
\hline T. viride + P. fluorescens & 31.3 & $65.19(53.81)$ \\
\hline T. viride + M. anisopliae & 25.9 & $71.15(57.50)$ \\
\hline T. viride + B. thuringiensis & 30.1 & $66.48(54.59)$ \\
\hline M. anisopliae $+P$. fluorescens & 36.1 & $59.82(50.65)$ \\
\hline B. thuringiensis $+P$. fluorescens & 54.1 & $39.85(39.12)$ \\
\hline M. anisopliae $+B$. thuringiensis & 34.7 & $61.30(51.51)$ \\
\hline T. viride + P. fluorescens + M. anisopliae & 24.5 & $72.71(58.48)$ \\
\hline T. viride + B. thuringiensis + P. fluorescens & 28.6 & $68.22(55.65)$ \\
\hline T. viride + B. thuringiensis + M. anisopliae & 23.2 & $74.19(59.43)$ \\
\hline P. fluorescens $+M$. anisopliae $+B$. thuringiensis & 32.9 & $62.70(52.33)$ \\
\hline \multirow[t]{2}{*}{$\begin{array}{l}\text { T. viride }+P . \text { fluorescens }+ \text { M. anisopliae }+ \\
\text { B. thuringiensis }\end{array}$} & 17.5 & $80.56(63.82)$ \\
\hline & \multicolumn{2}{|c|}{$\begin{array}{c}\text { S.Ed }( \pm)=0.77 \\
\mathrm{CD}_{0.05}=1.57\end{array}$} \\
\hline
\end{tabular}


Table.2 Effects of different consortial formulation on disease incidence (\%) of potted Micropropagated banana plants against Colletotrichum musae

\begin{tabular}{|c|c|c|}
\hline \multirow{2}{*}{ Treatments } & \multicolumn{2}{|c|}{ C. musae } \\
\hline & Disease incidence & Disease reduction \\
\hline $\begin{array}{l}\text { Root treatment with of } T . \text { viride }+P . \text { fluorescens }+M \text {. } \\
\text { anisopliae }+B \text {. thuringiensis (EM 1) }\end{array}$ & $28.1(32.01)$ & 11.74 \\
\hline $\begin{array}{l}\text { Root treatment with T. viride }+ \text { M. anisopliae }+P \text {. } \\
\text { fluorescens (EM 2) }\end{array}$ & $29.3(32.75)$ & 9.70 \\
\hline $\begin{array}{l}\text { Root treatment with T. viride }+ \text { M. anisopliae }+B . \\
\text { thuringiensis (EM 3) }\end{array}$ & $32.1(34.50)$ & 4.88 \\
\hline Root treatment of banana plantlets with EM $1+$ EM2 & $23.4(28.90)$ & 20.31 \\
\hline Root treatment of banana plantlets with EM $1+$ EM3 & $31.2(31.35)$ & 13.56 \\
\hline Root treatment of banana plantlets with EM 2+EM3 & $27.6(31.71)$ & 12.57 \\
\hline Root treatment of banana plantlets with EM1 + EM2+ EM3 & $18.3(25.30)$ & 30.24 \\
\hline Soil treatment of banana plantlets with EM 1 & $22.2(28.15)$ & 22.38 \\
\hline Soil treatment of banana plantlets with EM 2 & $23.4(28.95)$ & 20.18 \\
\hline Soil treatment of banana plantlets with EM 3 & $28.6(32.31)$ & 10.91 \\
\hline Soil treatment of banana plantlets with EM $1+$ EM 2 & $15.00(22.81)$ & 37.10 \\
\hline Soil treatment of banana plantlets with EM $1+$ EM 3 & $17.3(24.58)$ & 32.23 \\
\hline Soil treatment of banana plantlets with EM $2+$ EM 3 & $20.4(26.87)$ & 25.91 \\
\hline Soil treatment of banana plantlets with EM $1+$ EM2 + EM 3 & $13.5(21.55)$ & 40.58 \\
\hline \multirow[t]{2}{*}{ Control } & $35.00(36.27)$ & - \\
\hline & \multicolumn{2}{|c|}{$\begin{array}{c}\text { S.Ed }=0.16 \\
\text { CD0.05 }=0.32\end{array}$} \\
\hline
\end{tabular}

* Data in the parenthesis are angular transformed values

Table.3 Yield attributing characters of micropropagated banana plantlets due to application of Microbe based bioformulation and their consortia for management of $C$. musae

\begin{tabular}{|c|c|c|c|c|c|}
\hline \multirow[t]{2}{*}{ Treatment } & \multicolumn{5}{|c|}{ Yield attributing characters } \\
\hline & $\begin{array}{l}\text { No. of leaf } \\
\text { per plant }\end{array}$ & $\begin{array}{c}\text { Shoot } \\
\text { length } \\
(\mathrm{cm})\end{array}$ & $\begin{array}{l}\text { Shoot } \\
\text { girth } \\
\text { (cm) }\end{array}$ & $\begin{array}{c}\text { Root } \\
\text { length } \\
(\mathrm{cm})\end{array}$ & $\begin{array}{l}\text { No. of roots } \\
\text { per plant }\end{array}$ \\
\hline $\begin{array}{l}\text { Root treatment with of } T . \text { viride }+P . \text { fluorescens }+ \\
\text { M. anisopliae }+B . \text { thuringiensis (EM1) }\end{array}$ & 15.06 & 17.56 & 13.41 & 18.93 & 18.00 \\
\hline $\begin{array}{l}\text { Root treatment with, T. viride }+ \text { M. anisopliae }+B . \\
\text { thuringiensis (EM2) }\end{array}$ & 16.49 & 17.68 & 14.41 & 19.33 & 17.34 \\
\hline $\begin{array}{l}\text { Root treatment with } T . \text { viride }+M . \text { anisopliae }+P \text {. } \\
\text { fluorescens (EM3) }\end{array}$ & 15.54 & 17.55 & 13.70 & 18.74 & 15.89 \\
\hline $\begin{array}{l}\text { Root treatment of banana plantlets (RTBP) with } \\
\text { EM } 1 \text { + EM2 }\end{array}$ & 15.00 & 18.38 & 12.15 & 16.34 & 18.00 \\
\hline RTBP with EM $1+$ EM3 & 16.32 & 18.50 & 14.41 & 19.64 & 18.34 \\
\hline RTBP with EM 2+EM3 & 15.50 & 18.93 & 13.66 & 18.67 & 15.89 \\
\hline RTBP with EM1 + EM2+ EM3 & 18.42 & 21.13 & 15.70 & 20.00 & 19.67 \\
\hline $\begin{array}{l}\text { Soil treatment of banana plantlets (STBP) with EM } \\
1\end{array}$ & 15.36 & 17.87 & 15.68 & 19.35 & 18.34 \\
\hline STBP with EM 2 & 17.56 & 19.04 & 14.21 & 19.65 & 18.67 \\
\hline STBP with EM 3 & 16.33 & 19.58 & 15.70 & 19.95 & 20.24 \\
\hline STBP with EM 1+ EM 2 & 14.56 & 19.04 & 14.13 & 18.60 & 19.00 \\
\hline STBP with EM $1+$ EM 3 & 17.75 & 21.12 & 15.43 & 19.00 & 18.90 \\
\hline STBP with EM $2+$ EM 3 & 17.78 & 20.84 & 15.40 & 18.00 & 18.34 \\
\hline STBP with EM $1+$ EM2 + EM 3 & 19.05 & 21.41 & 16.77 & 20.34 & 20.34 \\
\hline \multirow[t]{2}{*}{ Control } & 13.99 & 17.55 & 12.06 & 13.34 & 14.34 \\
\hline & $\begin{array}{c}\text { S.Ed }( \pm) \\
=0.83 \\
\mathrm{CD}_{0.05}=1.69\end{array}$ & $\begin{array}{c}\text { S.Ed }( \pm) \\
=0.68 \\
\mathrm{CD}_{0.05}= \\
1.39\end{array}$ & $\begin{array}{c}\text { S.Ed }( \pm) \\
=0.56 \\
\mathrm{CD}_{0.05}= \\
1.15\end{array}$ & $\begin{array}{c}\text { S.Ed }( \pm) \\
=0.92 \\
\mathrm{CD}_{0.05}= \\
1.89\end{array}$ & $\begin{array}{c}\text { S.Ed }( \pm) \\
=0.81 \\
\mathrm{CD}_{0.05}=1.67\end{array}$ \\
\hline
\end{tabular}


Fig.1 Radial growth of different bioagents and their consortia suppressing growth of Colletotrichum musae in vitro

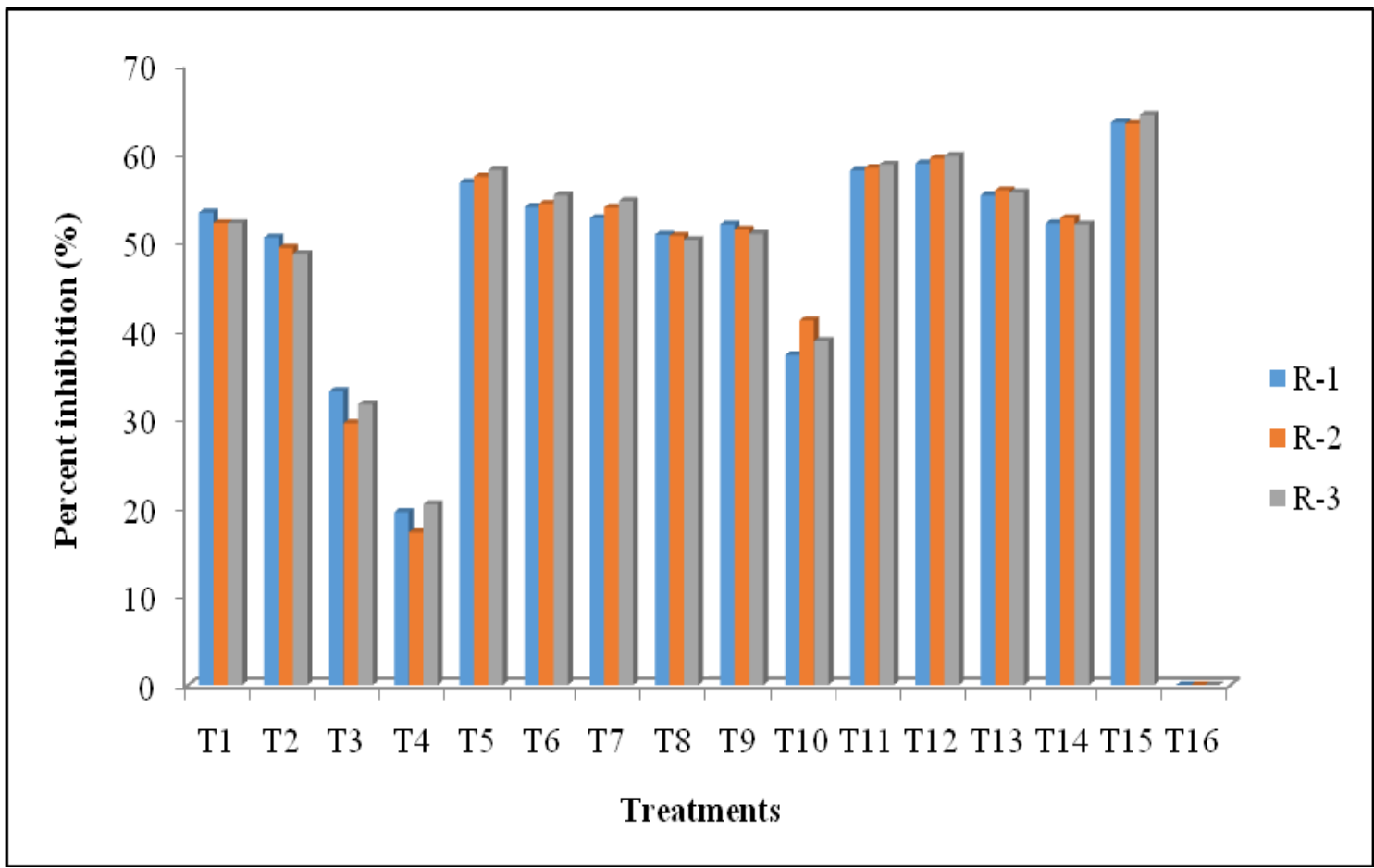

$\mathrm{T}_{1}=$ Trichoderma viride

$\mathrm{T}_{2}=$ Pseudomonas florescence

$\mathrm{T}_{3}=$ Metarhizium anisopliae

$\mathrm{T}_{4}=$ Bacillus thuringiensis

$\mathrm{T}_{5}=T$. viride $+P$. florescence

$\mathrm{T}_{6=} T$. viride $+M$. anisopliae

$\mathrm{T}_{7}=T$. viride $+B$. thuringiensis

$\mathrm{T}_{8}=P$. florescence $+M$. anisopliae

$\mathrm{T}_{9=} P$. florescence $+B$. thuringiensis

$\mathrm{T}_{10}=M$. anisopliae $+B$. thuringiensis

$\mathrm{T}_{11}=T$. viride $+P$. florescence $+M$. anisopliae

$\mathrm{T}_{12}=T$. viride $+P$. florescence $+B$. thuringiensis

$\mathrm{T}_{13}=T$. viride $+B$. thuringiensis $+M$. anisopliae

$\mathrm{T}_{14}=P$. florescence $+M$. anisopliae $+B$. thuringiensis

$\mathrm{T}_{15}=T$. viride $+P$. florescence $+M$. anisopliae $+B$. thuringiensis

$\mathrm{T}_{16}=$ Control 
Fig.2 Effects of different microbial consortia on disease incidence (\%) caused by

C. musae in micropropagated banana plantlets

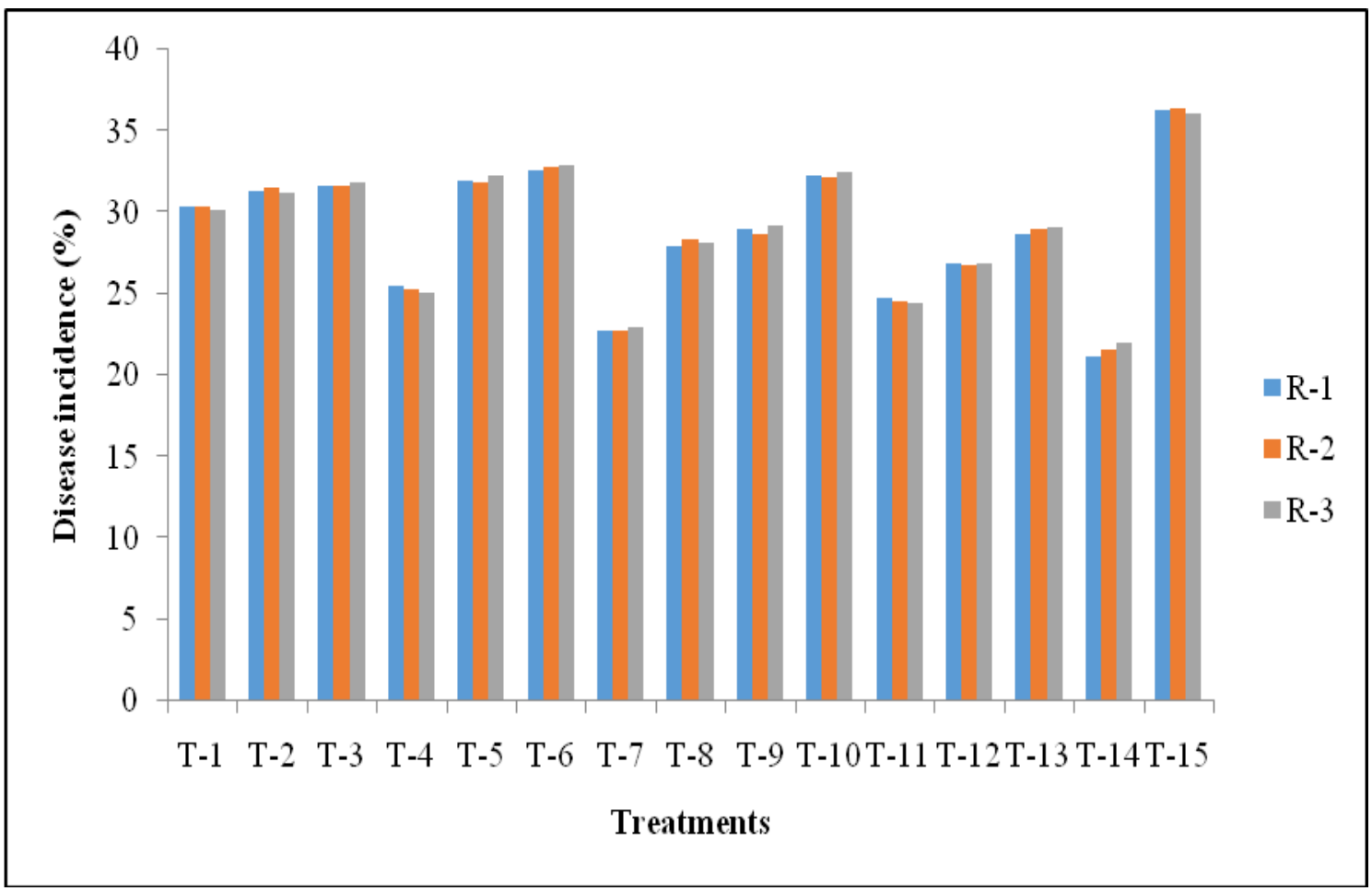

$\mathrm{T}_{1}=$ Root treatment of banana plantlets with Efficient Microbe 1 (T. viride, $M$. anisopliae, $P$. fluorescens and B. thuringiensis)

$\mathrm{T}_{2}=$ Root treatment of banana plantlets with EM 2 (T. viride, $B$. thuringiensis and M. anisopliae)

$\mathrm{T}_{3}=$ Root treatment of banana plantlets with EM 3 (T. viride, M. anisopliae and P. fluorescens)

$\mathrm{T}_{4}=$ Root treatment of banana plantlets with EM $1+$ EM2

$\mathrm{T}_{5}=$ Root treatment of banana plantlets with EM $1+\mathrm{EM} 3$

$\mathrm{T}_{6}=$ Root treatment of banana plantlets with EM 2+EM3

$\mathrm{T}_{7}=$ Root treatment of banana plantlets with EM $1+\mathrm{EM} 2+\mathrm{EM} 3$

$\mathrm{T}_{8}=$ Soil treatment of banana plantlets with Efficient Microbe 1

$\mathrm{T}_{9}=$ Soil treatment of banana plantlets with EM 2

$\mathrm{T}_{10}=$ Soil treatment of banana plantlets with EM 3

$\mathrm{T}_{11}=$ Soil treatment of banana plantlets with EM $1+$ EM2

$\mathrm{T}_{12}=$ Soil treatment of banana plantlets with EM $1+\mathrm{EM} 3$

$\mathrm{T}_{13}=$ Soil treatment of banana plantlets with EM 2+EM3

$\mathrm{T}_{14}=$ Soil treatment of banana plantlets with EM $1+\mathrm{EM} 2+\mathrm{EM} 3$

$\mathrm{T}_{15}=$ Control 
Plate.1 Typical symptom of Anthracnose of micropropagated banana caused by Colletotrichum musae
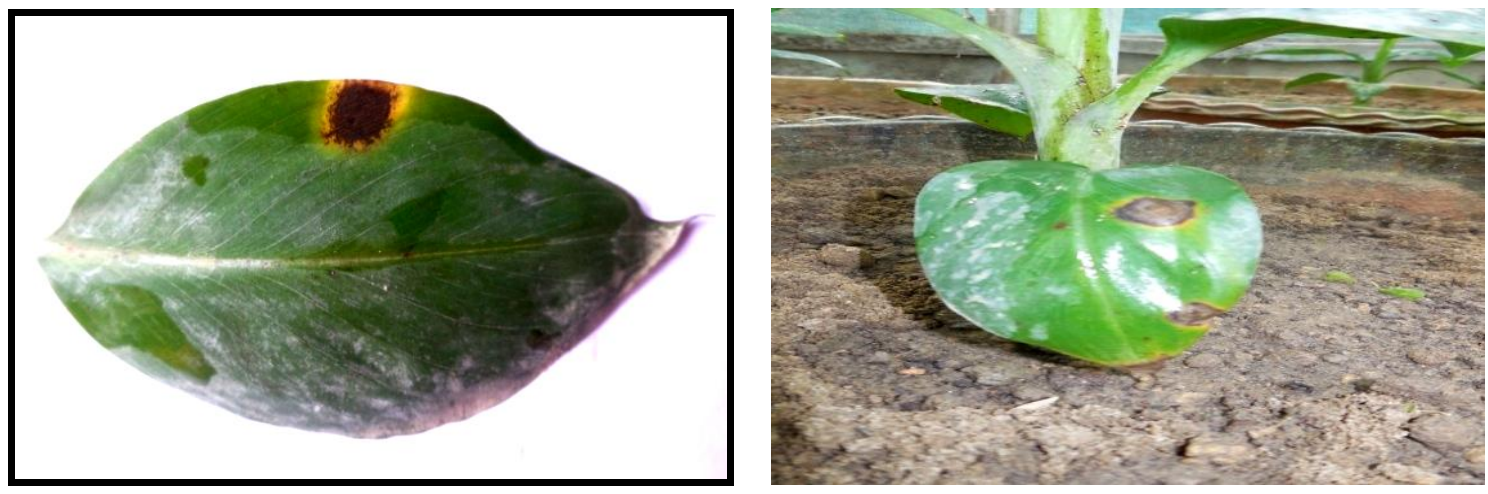

Plate.2 Cultural characterization of the pathogen (Colletotrichum musae)

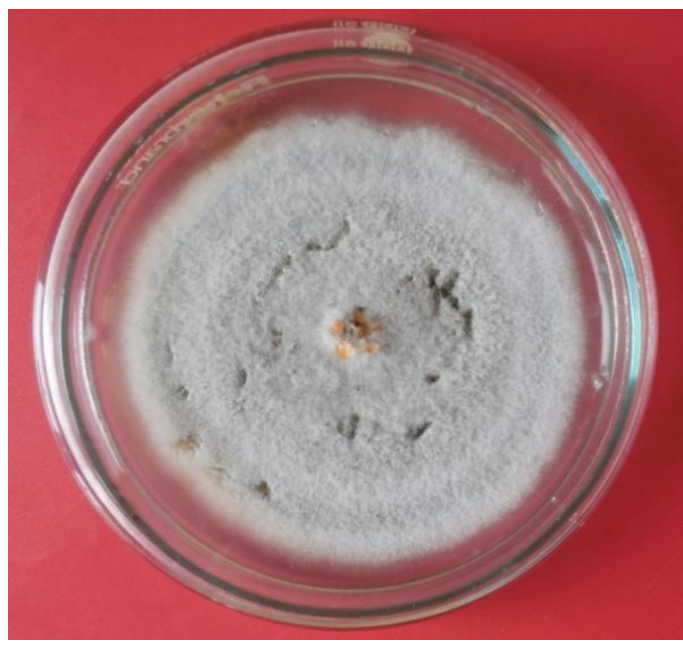

A. Pure culture of $C$. musae

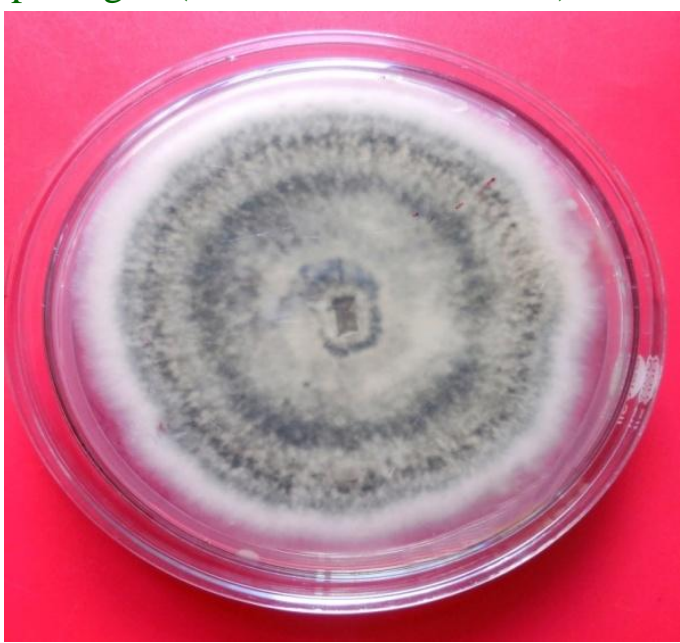

B. Back view of culture plate

Plate.3 Morphological characterization of the pathogen (Colletotrichum musae)

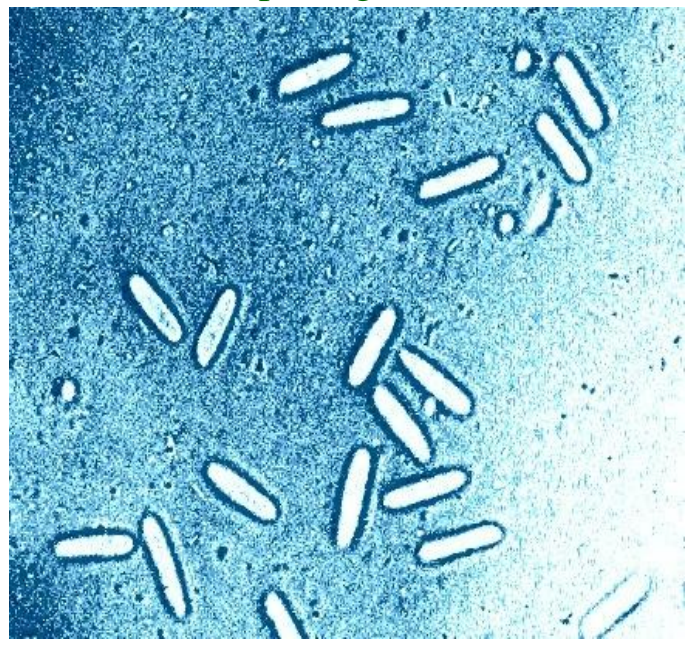

A. Conidia of C. musae

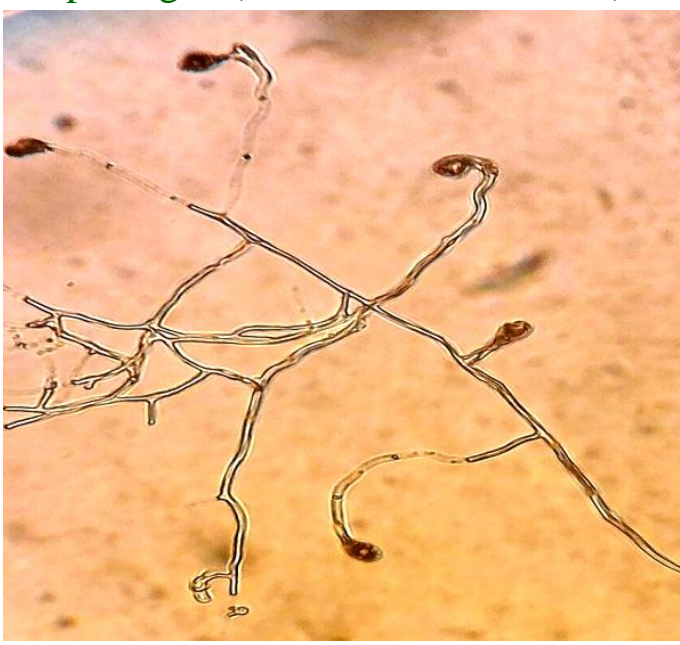

B. Appressoria formation of C. musae 
Plate.4 Pathogenicity test conducted with $C$. musae in micropropagated banana

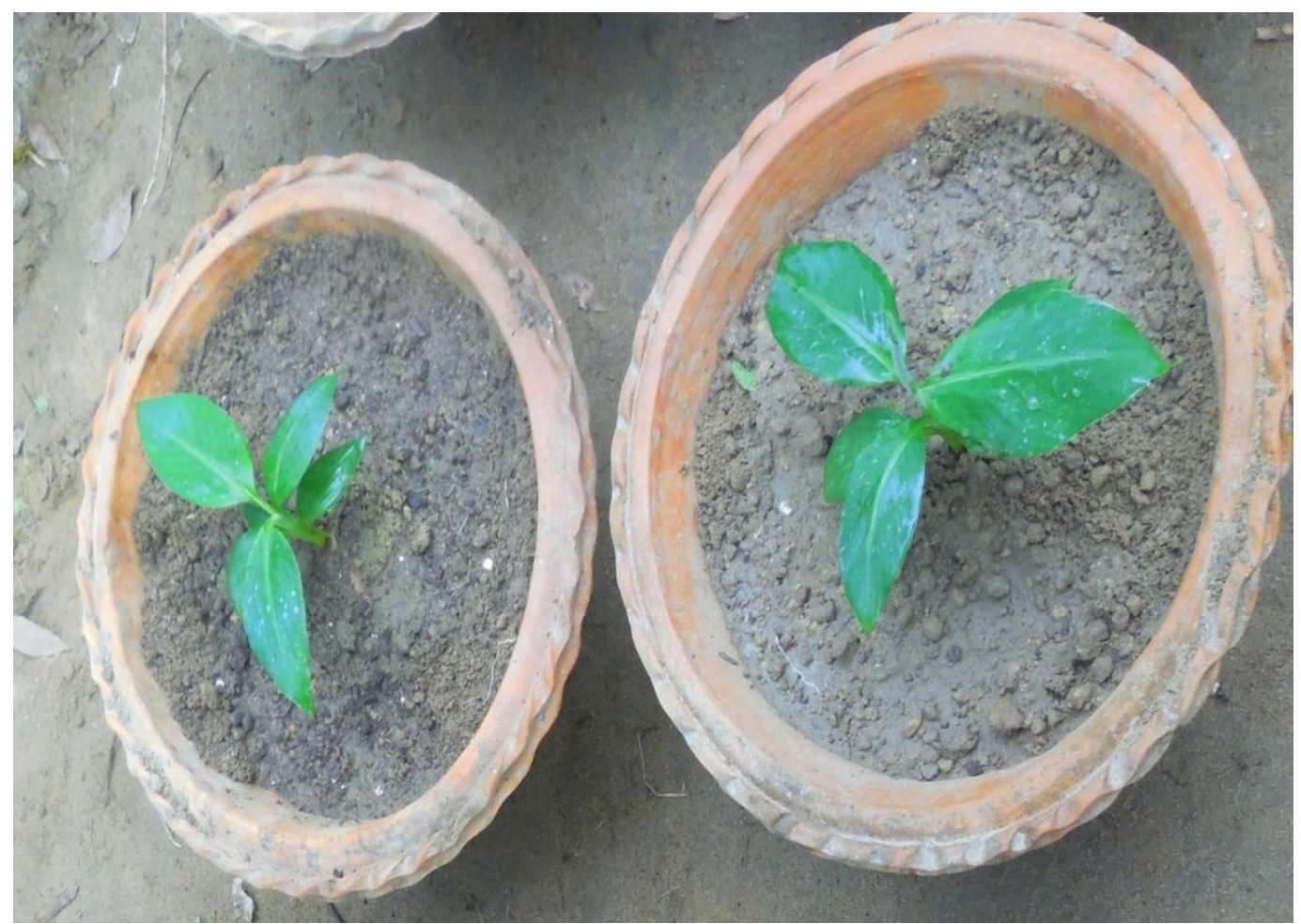

A. Healthy Micropropagated banana plantlets

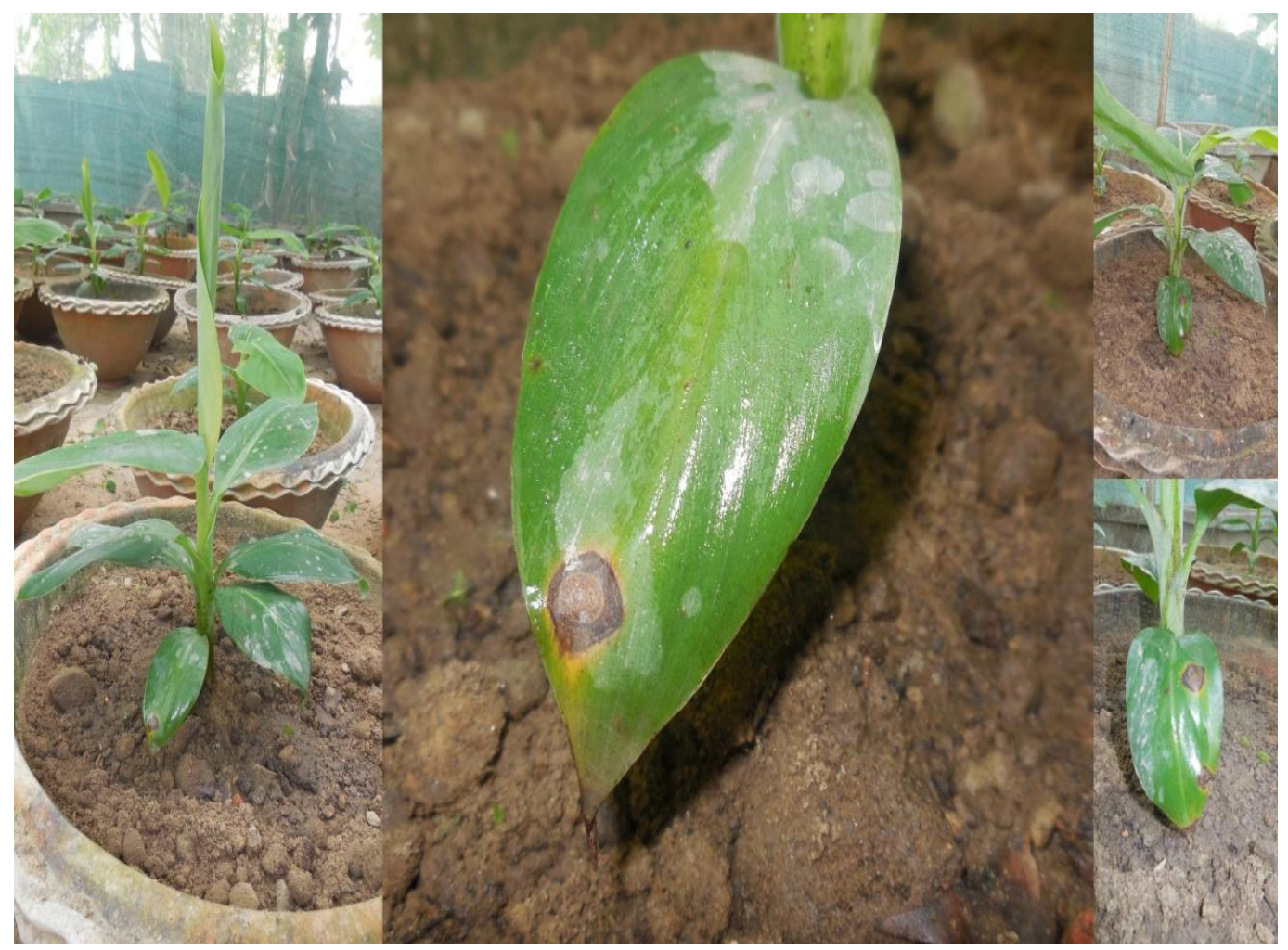

B. Infected Micropropagated Banana plantlets 
Int.J.Curr.Microbiol.App.Sci (2017) 6(7): 1673-1686

Plate.5 Growth of different microbial antagonists
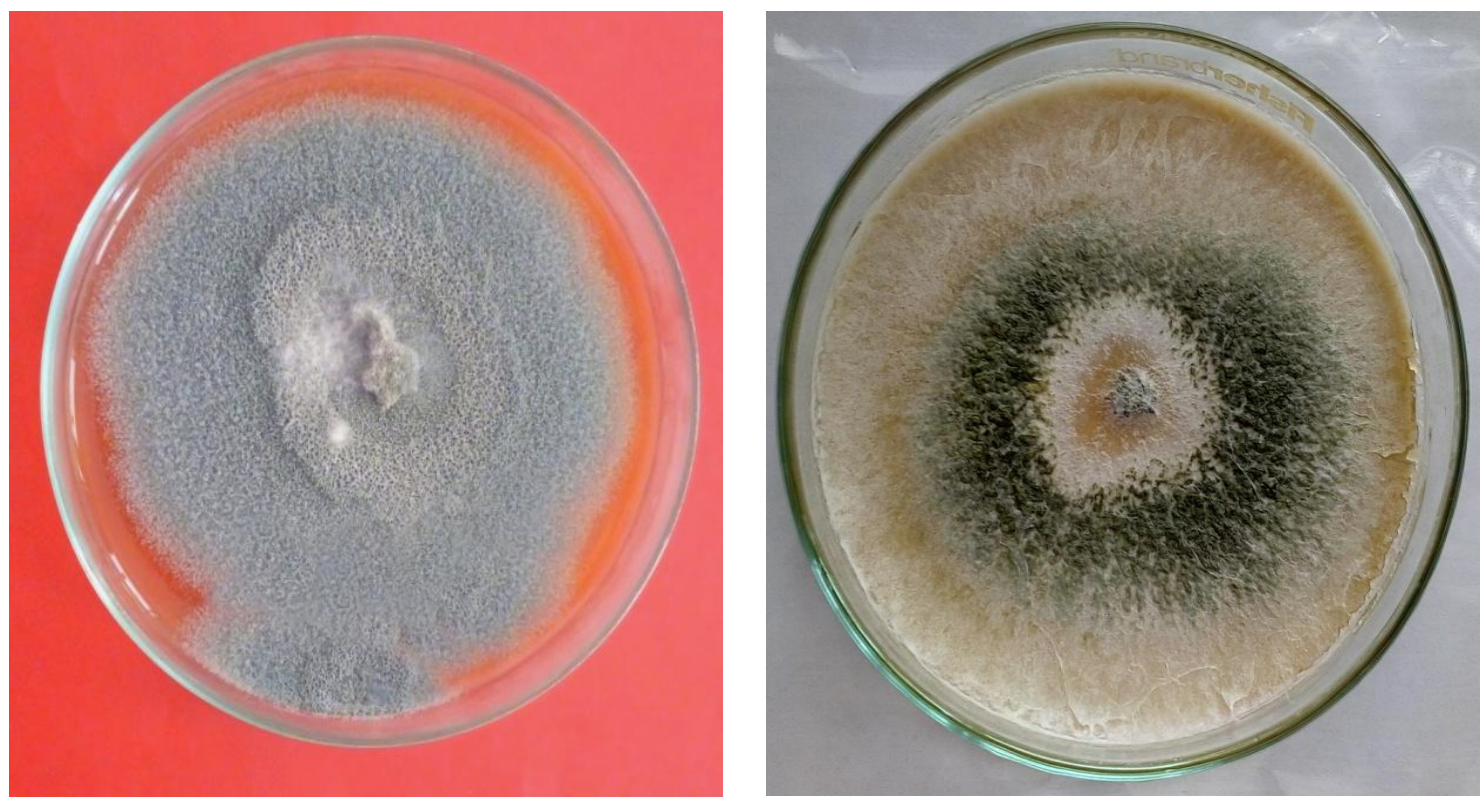

Metarhizium anisopliae

Trichoderma viride
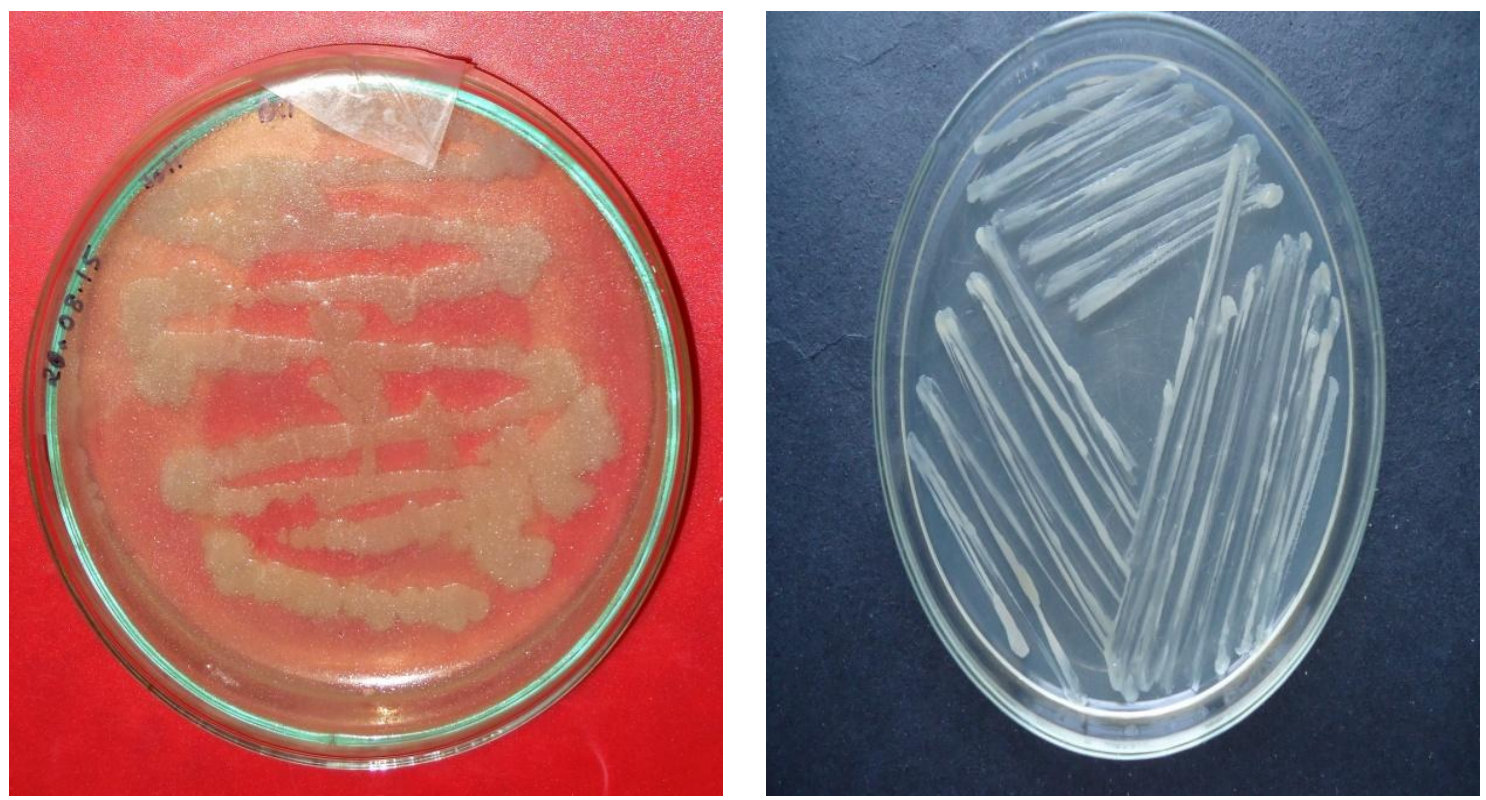

Bacillus thuringiensis

Pseudomonas fluorescens 
Plate.6 Antagonistic effect of different bioagents against $C$. musae

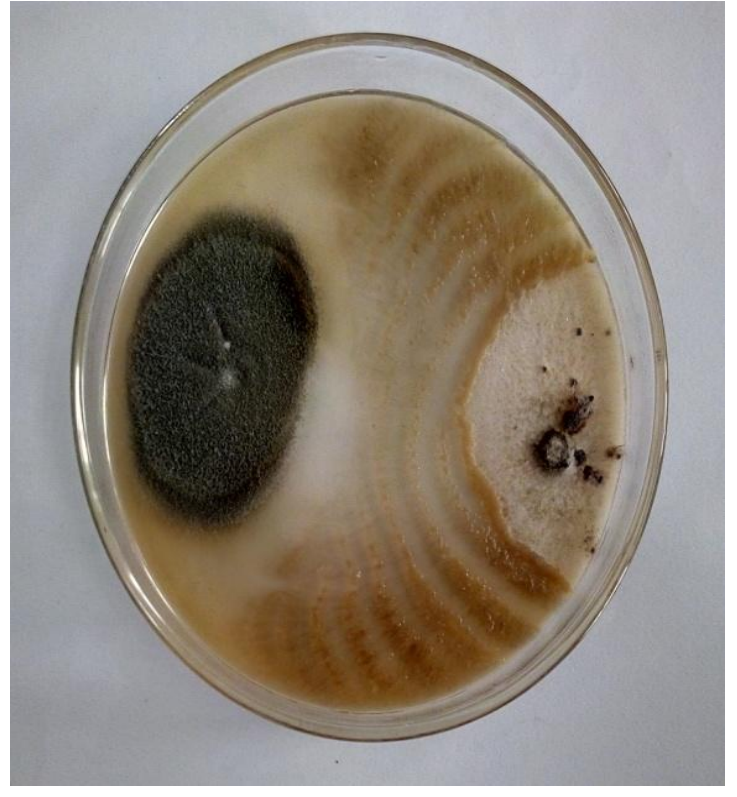

A) C. musae + M. anisopliae

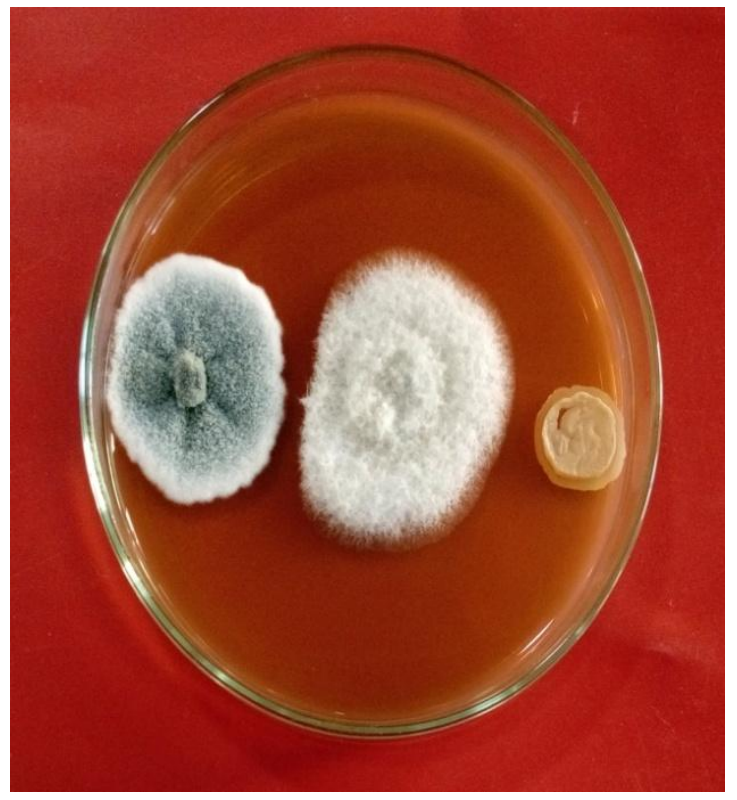

C) C. musae + M. anisopliae +

B. thuringiensis

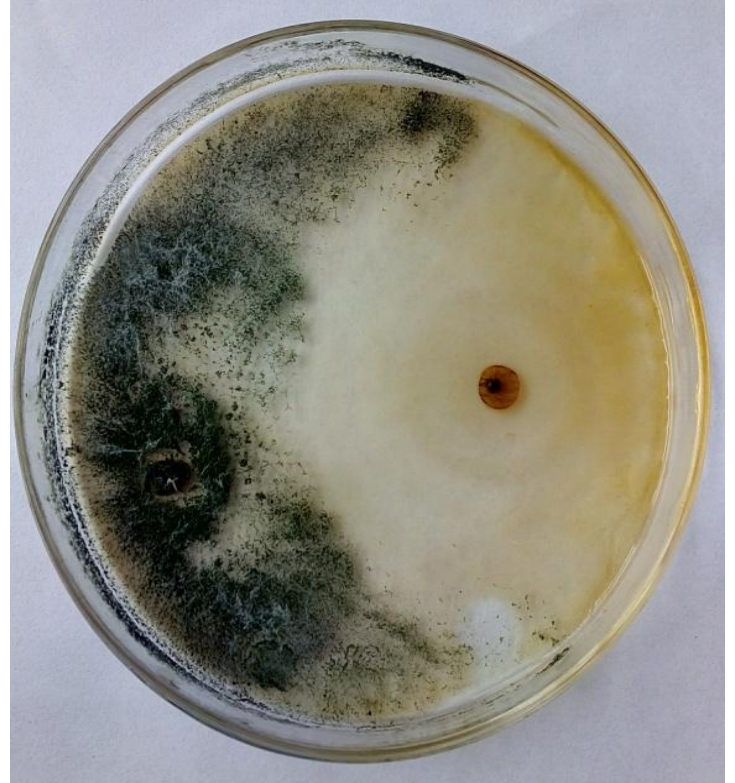

B) C. musae + T. viride

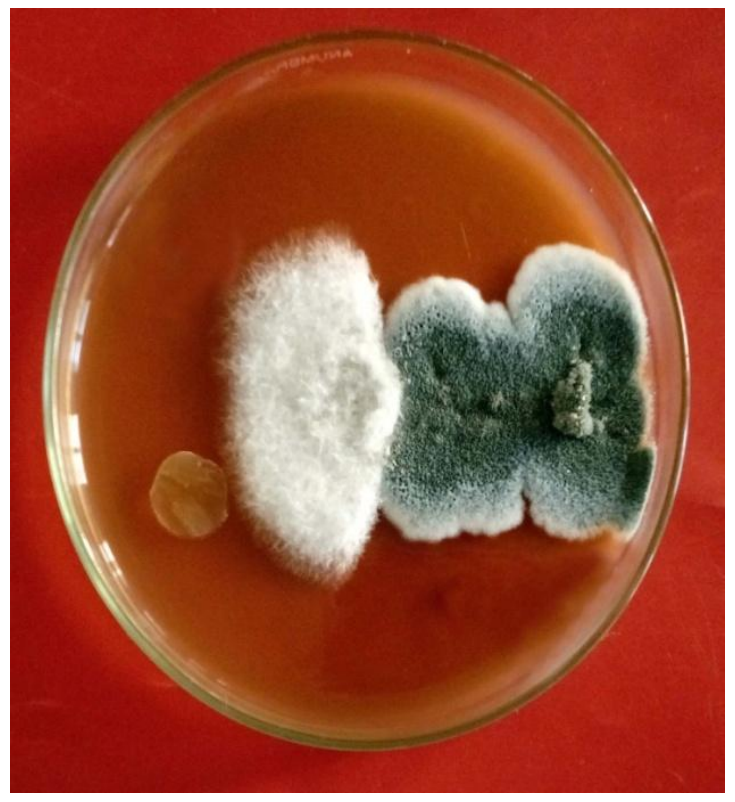

D) C. musae + P. fluorescens +

M. anisopliae 


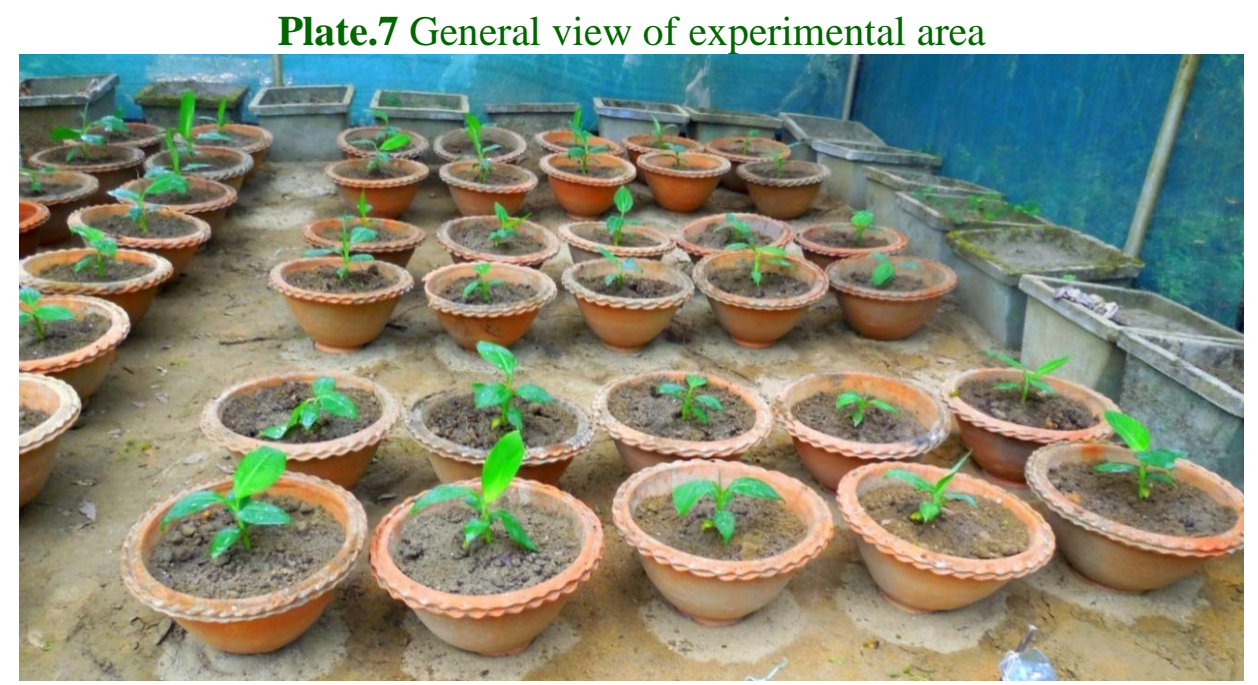

Plate.8 Application of consortial formulation for controlling Anthracnose disease

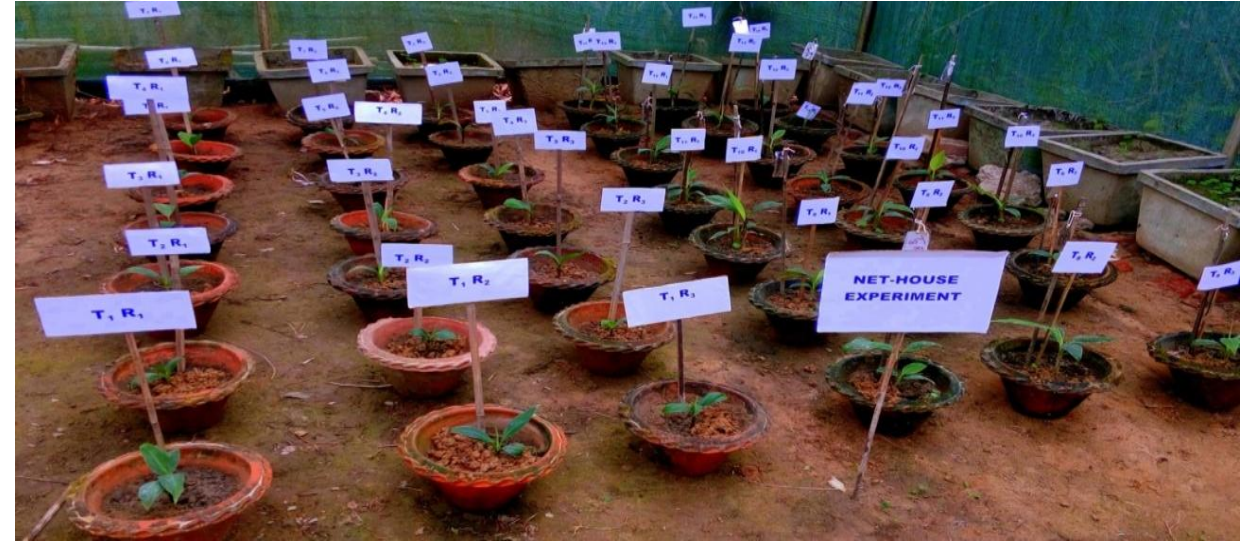

The fluorescent pseudomonads antagonize plant pathogens by producing a range of metabolites like antibiotics (Fravel, 1988), siderophores (Loper and Buyer, 1991) and other substances such as cyanide (Voisard et al., 1989). The main mechanism of the antagonism of $P$. fluorescens seems to be competition with pathogenic microorganisms for iron by release of siderophores which are secondary metabolites with an affinity to $\mathrm{Fe}^{3+}$ (Kloepper et al., 1993). Pseudomonas aeruginosa isolates showed potential antagonistic activity against $C$. musae causing anthracnose fruit rot of banana (Ranathunge et al., 2014). P. aeruginosa is capable of producing volatile substances and diffusible substances with antifungal properties that significantly inhibited the mycelia growth of C. musae.
Arokia Raj (2000) found that the bacterial antagonist $B$. subtilis could significantly reduce mycelial growth of $C$. musae. Similar observations were also made with Bacillus spp. antagonistic to Colletotrichum spp. (Sariah, 1994; Rahman et al., 2007). The Bacillus genus includes some species which are known to be endophytically active, and could play a key role in the biocontrol of pathogens like $C$. musae. $B$. subtilis and $B$. amyloliquefaciens were reported effective for the control of plant pathogens, due to production of iturin a cyclic lipo-polypeptide. The effective use of Bacillus as a biocontrol agent against $C$. musae on curcuma was reported by Mahadtanapuk et al., (2007).

Bioagents and their consortia based formulations for management of anthracnose of micropropagated banana 
Three best microbes based consortial formulations were applied as combinations of root and soil treatment for management of anthracnose of micropropagated banana. Consortial formulations of three best bioagents were prepared namely EM 1 ( $T$. viride, $M$. anisopliae, $P$. fluorescens and B. thuringiensis), EM 2 (T. viride, B. thuringiensis and $M$. anisopliae) and EM 3 (T. viride, M. anisopliae and $P$. fluorescens) and applied as root treatment and soil treatment in pot grown micropropagated banana plantlets for management of anthracnose disease. Soil treatment with EM 1 + EM 2 + EM 3 showed the best result in controlling anthracnose with least disease incidence (21.55\%). Highest disease reduction over control $(\%)$ was recorded in Soil treatment with EM 1 + EM 2 + EM 3 (40.58\%) (Tables 2 and 3; Figs. 1 and 2)).

The enhancement of yield attributing characters followed the trend of disease suppression as a result of the number of leaves per plant, shoot length, shoot girth, root length and number of roots per plant of micropropagated banana plantlets increased in Soil treatment with EM 1 + EM $2+$ EM 3.

\section{Acknowledgements}

Authors are sincerely thankful to the Department of Plant Pathology, Assam Agricultural University for providing necessary facilities to conduct the different experiments.

\section{References}

Alexopoulos, C. J., C. W. Mims and M. Blackwell. (1996). Introductory mycology. Wiley, New York, New York, USA.

Arokia, R.C. (2000). Biological Control of Fruit Rot in Banana Caused by Colletotrichum musae (Berk. and Curt.) Arx. and Botryodiplodia theobromae Pat. M.Sc., Thesis, Tamil Nadu Agricultural University, Coimbatore, India.

Bora, L.C. (2012). Interactive effect between different bioagents. Programme on
Biopesticides. Annual Report, DBT-AAU Centre. 2012-13. pp. 35-40.

Chatterjee, A., Cui, Y., Liu, Y., Dumenyo, C.K. and Chatterjee, A.K. 1995. Inactivation of rsmA leads to overproduction of extracellular pectinases, cellulases, and proteases in Erwinia carotovora subsp. carotovora in the absence of the starvation/cell density-sensing signal, N(3-oxohexanoyl) - L-homoserine lactone. Applied Environmental Microbiology 61.

Dagostin, S.; Perazzolli, M.; Ferrarib, A.; Elad.B.Y.and Pertota, I.(2008). Induction of systemic resistance against Plasmopara viticola in grapevine by Trichoderma harzianum T39 and benzothiadiazole. Biological Control, 47(2): p 228-234.

Deshwal V.K., Devi, M.S., Bhajanka, N, Mistri, J, Bose, A.; and Saini, N.(2011).Pseudomonas aeruginosa strains and their role in plant growth promotion in medicinal plant. Glo. J. App.Agric. Res, 1: 49-55.

Deuri, D. (2013) Bio-intensive approach for management of bacterial wilt of ginger (Zinziber officinale). M.Sc. (Agri) Thesis, Assam Agric. Univ., Jorhat, Assam.

Dowling, D.N. and O'Gara, F. (1994). Metabolities of Pseudomonas involved in the biocontrol of plant disease. Trends in Bio technology, 12:133-141.

Dunlap, C.; Crowley, J.J., Moinne-Loccoz, Y., Dowling, D.N., de Bruijn, F.J. and O'Gara F. (1997). Biological control of Pythium ultimum by Stenotrophomonas maltophilia W81 is mediated by an extracellular proteolytic activity. Microbiology, 143: 3921-3931.

Elad, Y.; Chet, I. and Katan, J. (1985). Trichoderma harzianum: a biocontrol agent effective against Sclerotium rolfsii and Rhizoctonia solani. Phytopathol. 70: 119-121.

Fravel, D. R. (1988). Role of antibiosis in the biocontrol of plant diseases. Annu. Rev. Phytopathol.26:75-91.

Freeman, S; Katan, T. and Shabi, E. (2004). Characterization of Colletotrichum species responsible for anthracnose 
diseases of various fruits. Plant Disease. 82 (6):596-605. doi: 10.1094/PDIS.1998.82.6.596.

Guetsky, R.; Shtienberg, D.; Elad, Y. and Dinoor, A. (2001). Combining biocontrol agents to reduce the variability of biological control. Phytopathology., 91: 621-627.

Jinyoung Lim.; Lim, T.H. and B. Cha. (2002). Isolation and Identification of Colletotrichum musae from Imported Bananas. Department of Agricultural Biology, Chungbuk National University, Cheongju, Korea, pp: 361-363.

Kang, S.C.; Bark, Y.G.; Lee, D.G. and Kim, H. (1996). Antifungal activities of Metarhizium anisopliae against Fusarium oxysporum, Botrytis cinerea, and Alternaria solani. Korean J. Mycol.24 (1): 49-55.

Kloepper, J.W.; Tuzun, S.; Liu, L. and Wei, G. (1993). Plant growth promoting rhizobacteria as inducers of systemic disease resistance. In: Pest Management: Biologically based technologies. Lumsden, R.D. and Vaugh, J.L. (Eds.). American chemical Society, Washington, USA, pp. 156-165.

Krauss, U. and Soberainis, W. (2001). Biocontrol of cocoa pod diseases with mycoparasite mixtures. Biol. Control. 22: 149-158.

Loper, J. E., and Buyer, J. S. (1991). Siderophores in microbial interactions of plant surfaces. Mol. Plant-Microbe Interact. 4:5-13.

Mahadtanapuk, S.; Sanguansermesri, M.; Cutler, R.W.; Sardsud, V. and Anuntalabhochai, S. (2007). Control of Anthracnose caused by Colletotrichum musae on Curcuma alismatifolia Gagnep using antagonistic Bacillus sp. Am.J.
Agric.Bio.Sci.2 (2):54-61

Meyling, N. and Eilenberg, J. (2007). Ecology of the entomopathogenic fungi Beauveria bassiana and Metarhizium anisopliae in temperate agroecosystems: Poten. Conserv. Biol. Ctrl. Biol. Ctrl.43: 145-155.

Narziya, N.F.: Costa, D.M.D. and Azhaar, A.S. (2007).Genomic variations of Colletotrichum musae morphophytes infecting banana varieties of Sri Lanka. Proc.Perad Univ Res Ses12:1-2.

Papavizas, G.C. (1985). Trichoderma and Gliocladium: Biology, ecology and potential for biocontrol. Ann. Rev. Phytopath.23: 23-54.

Rahman, M.A.; Kadir, J.; Mahmud, T.M.M.; Rahman, R.A., and Begum, M.M. (2007). Screening of antagonistic bacteria for biocontrol activities on Colletotrichum gloeosporioides in papaya. Asian J. Plant Sci. 6:12-20.

Ranathunge, N.P.; Gunathilaka, S.; Rajapaksha, J.C. and Rajapaksha, R.J.K. (2014). Screening of potential bacterial antagonism in aqueous extracts of spent oyster mushroom substrate against Colletotrichum gloeosporioides causing anthracnose disease in papaya. Proceedings of the $9^{\text {th }}$ Academic sessions of the University of Ruhuna, February 2012. pp. 71

Raupach, G.S.and Kloepper, J.W. (1998). Mixtures of plant growth-promoting rhizobacteria enhance biological control of multiple cucumber pathogens. Phytopathology 88:1158-1164.

Sariah, M. (1994). Potential of Bacillus spp. as a biocontrol agent for anthracnose fruit rot of chilli.Mol.Appl.Biol.23:53-60

\section{How to cite this article:}

Joli Dutta and Bora L. C. 2017. Pathogens associated with micropropagated banana plantlets and their management with microbial bioagents. Int.J.Curr.Microbiol.App.Sci. 6(7): 1673-1686. doi: https://doi.org/10.20546/ijcmas.2017.607.202 